\title{
Managing Biodiversity in Dealing with Sustainable Development Goals
}

\author{
${ }^{1}$ EKO PRIYO PURNOMO, 2 ETIKA KHAIRINA, ${ }^{3}$ MOCHAMMAD IQBAL \\ FADHLURROHMAN, ${ }^{4}$ BHIMO WIDYO ANDOKO, 5 AGUS PRIYANTO \\ ${ }^{12345}$ Universitas Muhammadiyah Yogyakarta, Jl Brawijaya, Geblagan,Taman Tirto Kasihan Bantul,55183 \\ Correspondence author: etikakhairina@gmail.com
}

\begin{abstract}
This paper aims to examine descriptively the management of biodiversity carried out by the Bantul Regency Government as part of sustainable development. Strengths such as conservation of biodiversity and protection of ecosystems by the Government must go hand in hand with sustainable development. The method used in this research is descriptive qualitative, using data analysis obtained by researchers from research results, journals, and the official website of the Bantul Regency Government. The results show that the strategy in managing biodiversity in Bantul Regency is the maintenance of biodiversity using an integrated approach and a long-term perspective. This is evidenced by management that integrates the conservation value of biodiversity ecosystems. The issuance of several Regional Regulations on Biodiversity Management is concrete evidence, ensuring that no extinction or damage occurs in biodiversity in Bantul Regency. Management activities will be a strong foundation for realizing sustainable development through various conservation approaches such as In-Situ and Ex-situ conservation to implement biodiversity management programs in Bantul Regency. Other strategies/ methods are creating areas/zones at several points of improvement in the area and their habitat while in the ecosystem.
\end{abstract}

Keywords: Management, Biodiversity, Sustainable Development Goal's

\section{Introduction}

This study aims to examine the management of biodiversity carried out by the Bantul Regency Government as part of sustainable development. Reflecting on several phenomena, the decline in biodiversity and damage to ecosystems causes various problems and severe human life threats. Various human activities put pressure on the earth so that environmental damage and damage to land and marine ecosystems cause enormous losses. Like the phenomenon of forest fires, deforestation will result in land destruction, loss of biodiversity, changes in climate patterns, depletion of the ozone layer, the greenhouse effect, global warming, avalanches, and floods. This phenomenon causes a high level of threat (Purnomo, Ramdani, Agustiyara, Tomaro, \& Samidjo, 2019; Rahadian, 2016; Rosana, 2018; Temel, Jones, Jones, \& Balint, 2018).
Human-induced loss of biodiversity has substantially reduced human use of nature (Opoku, 2019). Accordingly, the government has established a policy that must be in line with the concept of sustainability (Lepczyk et al., 2017). The gradual management of biodiversity must be in line with SDGs development so that the environment and humans can be sustainable. Sustainable Development Goals 19 (SDG19) attempts to protect, repair and encourage sustainable use of terrestrial habitats, sustainable forest management, the war against desertification, and the stopping and reversing of land degradation and biodiversity loss. (UNDP, 2016; United Nations, 2015).

According to Hermita, (2015), nature and the environment have a very close relationship with humans. Establish a human life depends on the use of biodiversity of nature such as soil, water, air, forests, and

Received: 2020-05-07, Revised: 2020-09-16, Accepted: 2020-12-23 
other natural resources. According to (Isbell et al., 2017), biodiversity is a term used to give you an idea of various forms of life on earth, the interaction between living things and their environment. Such communications will refer to all aspects of life: economic, social, environmental, science, ethics, and relation from one point to another. Of the surface area of the earth, $3 / 4$ or about 3 billion people depend on marine and coastal biodiversity for their livelihoods, where the oceans absorb about $30 \%$ of the carbon dioxide produced by human activity (UNDP, 2016). These conditions certainly require action and the role of the government as the party that carries out development. Development, of course, leads to changes towards the better and pay attention to environmental aspects.

The decreased of natural resources, biodiversity endangerment, destruction of ecosystems on land and at sea, is closely related to the course of human life (Ali, Kennedy, Kiesecker, \& Geng, 2018; Kopnina, 2017). Conserving biodiversity and protect the world's ecosystems has been agreed (by UN) and set as Sustainable Development Goals (SDGs); to conserve and use resources both on land and sea in a sustainable manner for the benefit of the community or improve the economy. The future that does not damage the environment by (Setyaningrum, 2017) state that globalization is encouraging several actions that may be detrimental to the survival of life, one of which is the decline in biodiversity due to destruction and extinction. The decrease in the number of biodiversity directly influences the urgent need for integrated planning and management in Indonesia that impacts on other aspects such as physical condition and social-economic. Biodiversity loss also increases environmental damage, in addition, that the government pay no attention to ecological aspects so that disaster such as flood frequently hit several cities in Indonesia (Ali et al., 2018; Gordon, Crofts, \& Díaz-Martínez, 2017; Liu \& Côté, 2017)

Ecological and economic relations have become essential factors in sustainable development. In line with the submitted by (Darajati et al., 2016; Duane, Harford, Ramasubbu, Stancliffe, Clewer, Lomax, 2019; Rosana, 2018), sustainable development must look at the environmental dimension, which means that the event is not necessarily done without thinking and looking at all aspects of life and other living things because people can continue living and rely on natural utilization. However, in recent years, an assessment of the phenomena occurred brings a pessimistic attitude on how to overcome the problem and encourages the government to make policy concepts. The Government with other stakeholders began to act towards environmental improvement as evidenced by the existence of (Yahya, 2016) ecosystem, approach programs, and activities such as (Arlis, Muhammadi, \& Chandra, 2018; Fatimah, 2018) conservation of ecosystems (Mangrove Ecosystem, Seagrass Beds, Coral Reefs, Etc).

The Bantul Regency Government has shown its seriousness in managing biodiversity in Bantul Regency by issuing several regulations, one of which is Bantul Regent Regulation number 284/2014 concerning Conservation Areas in Coastal Parks. Another example is managing Sect Code as Ecotourism in Yogyakarta (Fatimah, 2018). Some of the factors that threaten the sustainability of the ecosystem in Bantul Regency are land-use change and conversion, utilization of natural resources that are not environmentally sound, for example, mining activities, illegal/excessive logging of forests, hunting protected animals, etc. Environmental pollution occurs due to human activities. Introduction of foreign species and climate change. (Pramono, Lahuri, \& Ghozali, 2020) stated that every community group has its knowledge and ways of dealing with the environment for its survival.

Some scholars argue that conservation as a tourist attraction and frequented for materials research and tourism can bring economic value. But in the research of (Isbell et al., 2017), it is stated that conservation has not been well integrated into natural conservation policies that are dominated by biodiversity in influencing policies and practices for environmental management and preserving the earth's resources. According to (García-Llorente et al., 2018), conservation is a strategy to maintain an ecosystem. However, the implementation of conservation policies is still at an early stage because it tends to ignore the interests of local communities so that the ecosystem needs further attention. (Lin et al., 2017) use a conservation approach to protect habitats and ecosystems that have traditionally only focused on one habitat. A different thing is conveyed by (Moore, Ndobe, Ismi, Salanggon, \& Wahyudi, 2015) stating that the manta tow method is one of the methods used to maintain a minimal coral reef ecosystem. According to Zhang, 
Luo, Mallon, Li, \& Jiang, (2017), improving the efficiency of ecosystem conservation in China is carried out by a structural approach, practical strategies to improve organizational conflicts, improve community management, transparent allocation of conservation funding, strengthen supervision and mechanisms. Penalties are given for destructive activities and enhancing coordination capacity to improve coordination. According to (Purnomo, E. P., Nurmandi, 2016), to manage resources sustainably requires influence from local institutions because local organizations can better adapt and work to manage shared natural resources. According to (Rees, Foster, Langmead, Pittman, \& Johnson, 2018), implementing goals that emphasize the economic and social context of global development must integrate sustainable development with knowledge and progress to strengthen global efforts for biodiversity conservation.

Some ways or methods and approaches can be used in conserving biodiversity and efforts in environmental management to achieve sustainable development. According to (Drakel, 2010), environmental management can be understood as an integrated step to conserve biodiversity, including structuring, policies, utilization, development, maintenance, restoration, supervision, and control. To achieve sustainable development, improving and protecting ecosystems is carried out through forest management, taking a participatory approach with a focus group technique. (Ali et al., 2018; Gordon et al., 2017; Hermita, 2015; Prip, 2018). (Hardiyanti \& Aminah, 2019) One way to realize sustainable development is to conserve the area so that it can meet the community's current and future needs and build a forest management model that includes the role of the community as indigenous peoples and recipients of delegations. It is different according to the research of (Setyaningrum, 2017) stating that in preserving the mangrove ecosystem, the government collaborates with stakeholders as a third party to empower the community and use several empowerment methods ranging from training, nurseries, education, and surveying suitable mangrove routes. Developing mangrove ecotourism areas can be an alternative in maintaining environmental resilience (Ardiyansari, 2019).

This research tries to look at government policies to manage biodiversity and the application of sustainable development goals. Essential to optimize the potential of ecosystem conservation and environmental preservation, as the concept of sustainable development (Sustainable Development) (Arianti \& Satlita, 2018; Fatimah, 2018; Tristyana, 2018; Zhang et al., 2017). Because the concept of sustainable developmentcan be a perspective or reference for the government, society as well as the parties involved in related activities to be carried out in a planned and systematic way in terms of human welfare and the environment without reducing access and benefits for future generations (Ferrier et al., 2019).

Sustainable development in biodiversity aims directly at balancing the environment and nature. (Gull et al., 2017) stated that the political agenda for sustainable development is a world/global construction. According to (Rahadian, 2016), strategies in sustainable development are the equal distribution of the benefits of development results between generations, safeguarding the preservation of natural resources and the environment, and utilizing natural resources solely for intergenerational interconnection.

At the same time, ecology and economy have a significant relationship with sustainable development itself (Khairina, Purnomo \& Malawnai, 2020). The inclusion of conservation such as mangrove preservation and other natural preservation in Bantul Regency as a step in natural resource management and environmental protection in the concept of sustainable development is very interesting to be discussed in this study by looking at government policies in natural resources. It also examines the management of biodiversity in sustainable development and what the government does in managing biodiversity in Bantul Regency.

\section{Research Methods}

The method used in this research is a case study by paying attention to several objects and assisted by the phenomenological approach to explore data and find the essential points of some of the items studied. This is according to what was conveyed by (Mudjia, 2017) that the case study will obtain in-depth, intensive, and detailed about an activity, program, event at the level of individuals, institutions, and organizations. (Rahardjo, 2018) conveying that phenomenology is a study of how to describe something experienced through the senses alone. For more specific results, data from policies in natural resource management (ecosystem 
conservation or other natural preservation) were collected from searching the official website of the Bantul Regency government, especially the Bantul Regency Environmental Agency, and observations and literature studies as support. The data collection technique was carried out using purposive sampling by directly seeking data and information from those directly related to this study. The field results will be analyzed using qualitative analysis, describing the data and facts logically, then formulating conclusions about the natural resource management policies of the Bantul government in the concept of Sustainable Development.

Sustainable development has become a global agreement, including in terms of biodiversity management. According to UN agreement, biodiversity is closely related to

Table 1

Overview of Biodiversity Target
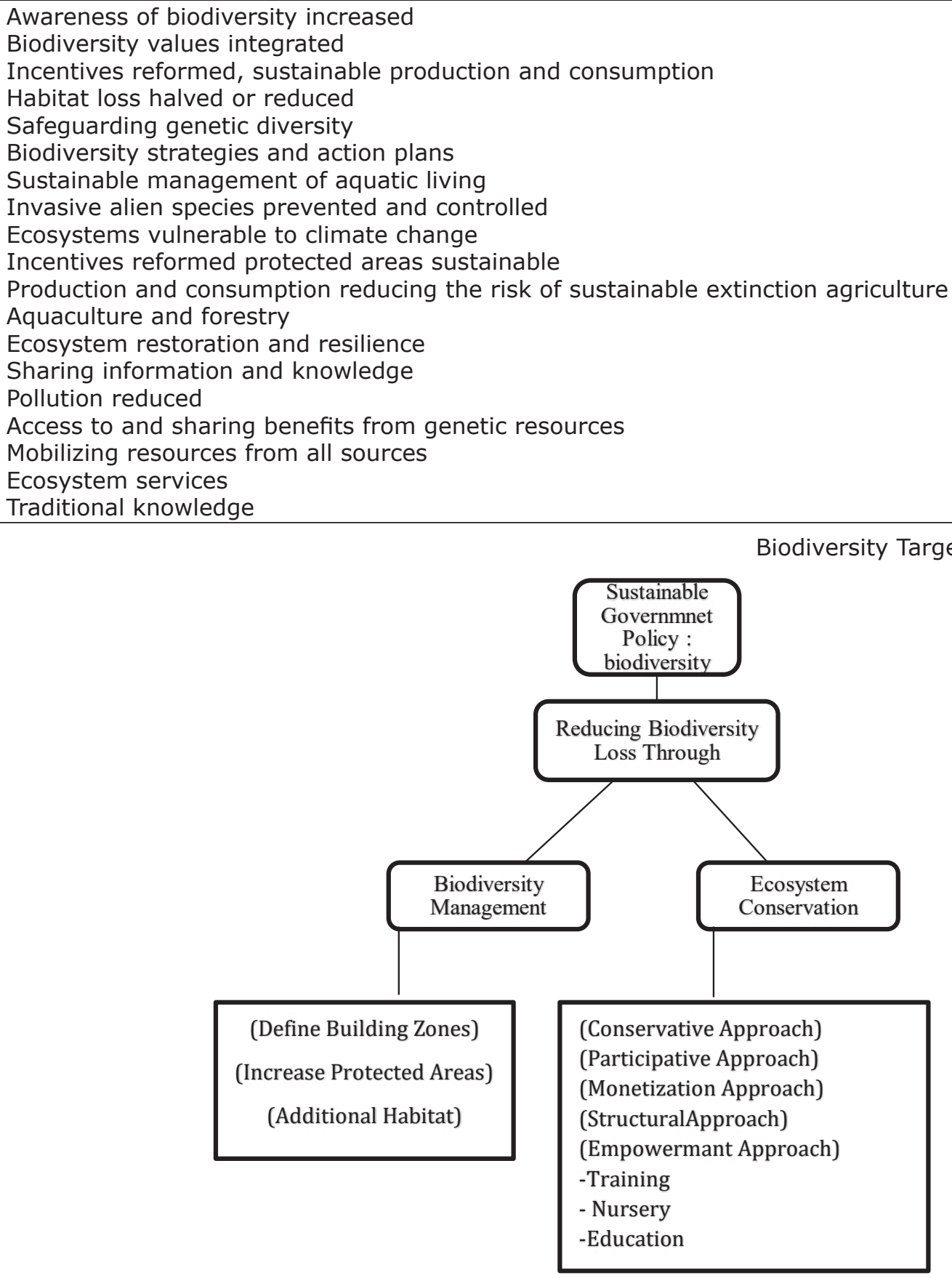

Figure 1. Management of Biodiversity in Sustainable Development adopted from (Opoku, 2019) 
the targets in points 14 and 15 in the SDGs Concept. The description of the Biodiversity management targets that have been set by the United Nations as part of the Sustainable Development Goals (SDGs) can be seen in Table 1.

\section{Results And Discussion}

\section{Management of Biodiversity and Sus- tainable Development}

The impact of sustainable development is local and global; much of the world feels the effects of progress on development. Sustainable development (Rahadian, 2016) aims to improve people's welfare for a better life. The creation of sustainable development in Indonesia reminds us that humans must enhance the quality of life by keeping on trying and not going beyond the ecosystem that supports their life. Sustainable development is essential for the life of the world community in the future. Managing biodiversity is one of the main ideas in sustainable development. Phenomena such as floods, land degradation, loss of biodiversity, changes in climate patterns, depletion of the ozone layer, the greenhouse effect, global warming, and landslides are forms of negative consequences of development that ignore the concept of sustainable development.

The concept of sustainable development tries to balance social and environmental sectors. The environment becomes a supplier of natural resources, a source of human needs; then, it provides human resources as a subject in development. This development will bring impacts and risks to ecosystem changes. Therefore, development activities must be sustainable for future generations. One of the indicators used and agreed upon by the United Nations is maintaining and preserving biodiversity in each region. The environment is a significant factor in the loss of biodiversity. Humans and nature usually cause a loss of biodiversity (Opoku, 2019). For sustainable development, it is necessary to increase ecological values.

Management of biodiversity and ecosystems is inseparable from the drive for economic needs. The use of natural resources, including biodiversity and ecosystem by the government, does not only have one target, and utilization must have an impact on many aspects (Rahadian, 2016). They are using natural resources based on government decisions such as economic growth and maintaining the environment's beauty.
(Opoku, 2019) stated that economic needs will drive most policies, especially biodiversity management. Ecosystem and biodiversity management will refer to government regulations in its implementation (Duane, Harford, Ramasubbu, Stancliffe, Clewer, Lomax, 2019).

Utilization of natural resources that cause damage and threaten the preservation of biodiversity must be resolved immediately. Sustainable development must pay attention to the environment, such as developing protected areas. (Fatimah, 2018) stated that this approach is a form of empowerment for the local community; the policy is made by the government, especially to protect forests from damage. The amount of forest degradation is massive, and the government cannot just ignore this situation. Conditions that become a consideration or priority for Bantul Regency in development planning are those that have significant impact on the region/community in the future, while strategic issues designed with biodiversity in Bantul Regency are conservation in several ecosystems, change in land function, waste management, optimization of green space in cities and strategic areas, disaster migration, and environmental pollution.

Bantul Regency Government has established strategic steps in preserving biodiversity in Bantul Regency, one of which is conservation activities; the conservation strategy undertaken is ex-situ and in-situ preservation. conservation is carried out so that it can work sustainably for the welfare of the community. Stated that the wealth of flora and fauna is a potential that can exploit to a certain extent that does not interfere with sustainability (Kuspriyanto, 2015). The decrease in the number and quality life of flora and fauna is controlled through conservation activities both in-situ and ex-situ.

The Ex-situ conservation carried out by Bantul district government is the Mangunan Fruit Garden located in Mangunan Village, Imogiri District, with an area of 25 hectares, which is also used as an agro tourism area by the local community. In situ conservation in Bantul district, namely a Nature Reserve located in Wukirsari Village and Girirejo, Imogiri sub-district with an area of 11.4 hectares. There are land uses that are not under the management: water reservoirs, asphalt roads leading to the king's tomb, and sub-districts villages (Bantul Regency Environmental Service 2013). Furthermore, 
the existence of endemic species is also a concern that they must be protected. One of the identities of Bantul Regency's plants is Sawo Kecik (Manilkara Kauki). This plant benefits in creating a shady environment and has an economic value; the wood, which is already well known, is often used for wood carving crafts. Initially, sapodilla trees in Javanese society were found in the houses of aristocrats and palaces.

For this reason, the existence of such typical plant must be maintained so that future generations can see and use it. Several types of plants and fauna are protected by the government Bantul Regency, which was founded in 2009, including Sawo Kecik, Ketepeng, Gayam, Jambe/Pinang Jawa, and Pelem Jawa. Meanwhile, protected fauna includes squirrels, whirlwinds, owls, starlings, kestrels, turtledoves, egrets, ravens, lizards, turtles, and porpoises. Based on the types, some of them are extinct. Environmental management is crucial, such as regulation on electricity that can both benefit and damage the ecosystem and the environment.

Therefore, the government must take specific steps to maintain the ecosystem and sustainability of flora and fauna for future generations. To ensure the sustainability of all species and the survival of biological communities and maintain ecosystem functions are very important in managing biodiversity and ecosystems. Humans as part of the ecosystem mean their assessment will affect the goals of ecosystem management. By using the strategy in sustainable development (Rahadian, 2016), several concepts implemented by Bantul Regency that need to be considered are equity, participation, diversity, integration, and longterm perspectives. Therefore, it is necessary to develop a shared understanding that the management of biodiversity as part of a resource in a sustainable manner will provide long-term benefits for future generations.

Sustainable development goal's (SDGs) is a development that will never stop; the life of future generations must be better and not less from the current level of experience, in the sense that today's generation can use various ways and choices in using resources. However, the existence of natural resources has to be preserved; despite having a small number of natural resources, future generations should have a better level of technology and knowledge and maintaining those resources availability and not exploiting them. (Lepczyk et al., 2017) Future generations must be prosperous and said to be sustainable if there are no problems of inequality between generations. Biodiversity is an asset for regional and national development that needs integrated management between sectors and government levels.

The seriousness of Bantul Regency Government in managing biodiversity has long been implemented, as seen from the making of Bantul Regency Regional regulations regarding biodiversity policies, this policy can see in Table 2 .

\section{Table 2}

\section{Regulations Of biodiversity management}

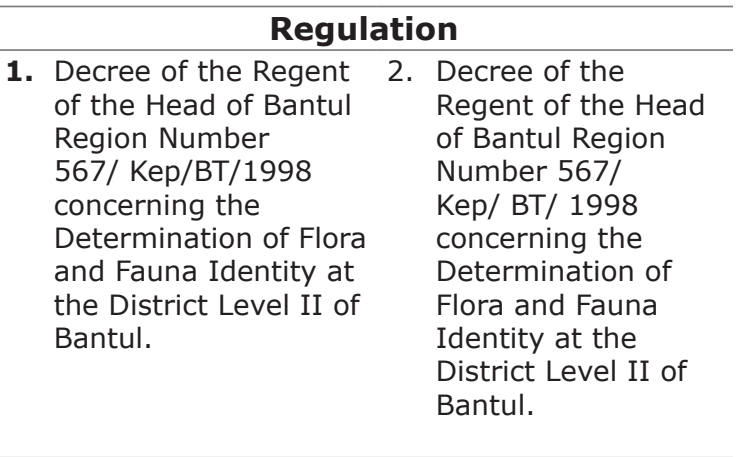

Source: Bantul Regency Government environmental services

Living natural resources and ecosystems have a vital position in human life so that they need to be managed and utilized. Biological natural resources in the form of animals that live on land, air, and water need to be protected and preserved to avoid actions that harm the environment and excessive use that causes extinction.

\section{Ecosystem Conservation Conservation of Birds and Fish in
Bantul Regency}

On May 12, 2016, Bantul Regency has arranged the preservation of birds and fish in Bantul Regency (DLH Bantul Regency). The protection is regulated in the Regent Regulation No. 24 of 2016 concerning Birds and Fish's Conservation. The issuance of regulations to preserve birds and fish is related to hunting, breeding, and utilization activities carried out by everyone. Conservation strives for the survival of birds and fish against businesses that threaten their lives. Besides preservation of animals in Bantul area, the regulation on the conservation of birds and fish also aims 
to avoid the danger of extinction, protect the genetic purity and diversity of animal species, and maintain the ecosystem's balance. Based on the regulations, factors that can threaten ecosystems' sustainability are changes and land-use change, the use of natural resources that are not environmentally friendly such as mining activities, illegal logging, hunting of protected animals, environmental pollution due to human activities, and climate change.

\section{Addition of Turtle Habitat in the Coastal Area of Bantul Beach}

In 2014, Bantul district and Department of Maritime Affairs and Fisheries established turtle conservation in Bantul coastal area. The types of turtle conserved include leatherback turtle, loggerhead turtle, green turtle, hawksbill turtle, ash turtle, and flat turtle. New coastal areas, pine caves beaches, and rainbow beaches are following the Decree of the Regent of Bantul in 2014 concerning the Reservation of Coastal Park Conservation Areas.

The purpose of conservation is to conserve animals that live on land and in the sea. The searching of turtle eggs will be carried out from May to September; after the turtle eggs are hatched and found in the turtle, then three after, the eggs will be released to the sea to be able to live freely until they grow big and return to the surface to lay eggs again (DKP Istiwanto). Of the four beaches, the one that has the most abundant turtle eggs for conservation is the rainbow beach with 14 nests which have 60-70 nest eggs (Istiwanto).

The conservation management is also directed as the empowerment of coastal communities in the Bantul Regency. To continue to preserve the conservation of sea turtles on the Bantul coast, it is necessary for people from the city to have awareness and protect the beach and understand how to handle turtle eggs when they find ones, given the natural conditions that significantly affect the conservation. (Monev Agung Budiantoro) explain that the state of a clean coastal area will affect the sea turtle that will land. As a partner of the government in carrying out conservation, the community is expected to be able to protect the environment and prevent turtles from extinction as intended by the Bantul district government and the marine and fisheries service.

Agung Budiantoro, a Biology lecturer at UAD Yogyakarta and at the same time as an officer conducting Monitoring and Evaluation (Monev), provided an understanding to the public in 2013 and 2014, the Bantul district government and the Maritime Affairs and Fisheries Office (DKP) focused on building and training the community. The conservation activities carried out to maintain protection can be seen in Table 3.

The program is one of the empowerment approach methods by providing training, care, and education to local communities to conserve and protect ecosystems and the environment. This is in line with what the (Widyanto, Mulatsih, \& Karlinasari, 2019) conveyed that the empowerment approach is quite significant. It is one of the most likely factors to open up the community's perspective to new things.

Increasing Protected Areas and Determining Building Zones in Bantul Regency Beach Park.

Conservation of Bantul Regency Coastal Park. Bantul Regency coastal area, located in the village of Tirtohargo Kretek Bantul, has attractive biological resources and potential natural resources in the form of sea turtles mangrove vegetation. The Coastal ParkConservation Area consists of land and sea areas, namely the Turtle Conservation Area, covering an area of 50 hectares, and the Baros Mangrove Conservation Area, covering 132 hectares with the management carried out by Bantul Regency's marine and fisheries service. The Baros Mangrove conservation area is a conscious effort of Bantul district government and the community to save the southern coastal area (Baros Beach) from coastal abrasion and save agricultural land around the coast salt-containing water often permeates agricultural land.

The division of zone is one of the management stipulated by the Bantul district government to save the mangrove ecosystem. Zoning in several forest areas plays a role in mitigating floods, landslides, and drought (Bahagia, Wibowo, Mangunjaya, \& Priatna, 2020). Efforts to protect and preserve the biodiversity of Baros mangrove ecosystem are determined through the Decree of the Regent of Bantul Regency No. 284 of 2014 concerning the Reserving Conservation Area, which consists of three zones: the core zone (10 ha), the other zone (94 ha), and the limited-use zone (28 ha). Details of division zones listed in the Indonesian Minister of Maritime Affairs and Fisheries Regulation No. 17/Men/2008 are as follows: 
Table 3

Conservation Program in 2013-2014

The year 2013

The year 2014

Pusdatin Building construction (data and information Training in the field of excellent service for the center) so that visitors know the data and community. The need for training and assistance information about the conservation of sea turtles in in the field of tourism potential management by the area as a development of supporting facilities improving its human resources in order to be for turtle conservation areas. able to serve tourists well and be able to develop their own potential as a tourist attraction

Construction of public facilities such as toilets to The socialization of activities in the area around support conservation areas must be reproduced Sanden sub-district is an effort to socialize the again conservation areas and to transfer knowledge about the conservation of endangered animals vulnerable to extinction

Procurement of information boards regarding the Training of Trainer (TOT) based on Turtle closing of certain areas which become turtles landing Conservation Ecotourism to Pokdarwis and Turtle places at certain hours, a signpost for educational Conservation Groups so that they can become sites for turtles, and so on tour guides in their own area

Publication about turtle conservation areas, either Training in making miniature coral reefs as a through web, pamphlets, or other media natural habitat for turtles.

Training for tour guides who are members of Collection of biological and ecological data on the Pokdarwis (Tourism Awareness Group) to be turtle landing on Bantul Beach and the creation able to have quality of human resources in turtle of a turtle conservation database to support conservation tourism marketing ecotourism sites in Goa Cemara Beach.

Providing Microchip Reader Tagging for the Mino The socialization of zonation of sea turtle Raharjo turtle conservation group on Goa Cemara conservation areas as a plan of action after the Beach, Patihan. enactment of the Bantul Regent's Regulation regarding Reservation Areas of Coastal Parks

Source: UAD university

1. core zone as a spawning ground area, nesting site, nursery ground, feeding ground for fish and another aquatic biota, and also coastal and small islands ecosystems vulnerable to change;

2. the limited use zone is a habitat for fish and population protection, tourism, recreational research, and education;

3. zones outside the core and utilization zones are limited because their functions and conditions are defined as certain zones such as rehabilitation zones. The zone can be seen in Figure 2 (the map below).

The Baros mangrove area as a nature reserve for the coastal park conservation area of Bantul Regency can be utilized and strengthen the community's economy. as seen in the division of the area according to the regulations (figure 2), therefore it needs to be protected and managed greatly by considering the physical, biological and economic functions and benefits that can improve the welfare of the community, especially those who live around the area/ Zone.

Strategic Biodiversity Plan and the
Aichi Biodiversity Goals adopted under the Convention Biological diversity have been recognized as establishing the global context for biodiversity priority actions (UNDP, 2016). The 2030 agenda is aligned with other international agreements currently in place like the Strategic Strategy for Biological Diversity. The SDGs and the Strategic Plan are supporting one another. Connections between SDGs and Biodiversity Goals in supporting one another is the SDGs and the Strategic Plan. Bantul Regency has the potential for natural resources managed by several approaches/ methods in fish and bird breeding, sea turtle conservation at several coastal points, and mangrove vegetation, which has an attraction for biological natural resources, geological formations, and natural phenomena that can be developed for the benefit of scientific development, research, education and increasing awareness of the conservation of living natural resources, marine tourism, and recreation as part of the concept of sustainable development. The management is carried out by the Bantul Regency Marine and Fisheries Office by creating a conservation area management plan, announcing and disseminating the Conservation Area Reserve 


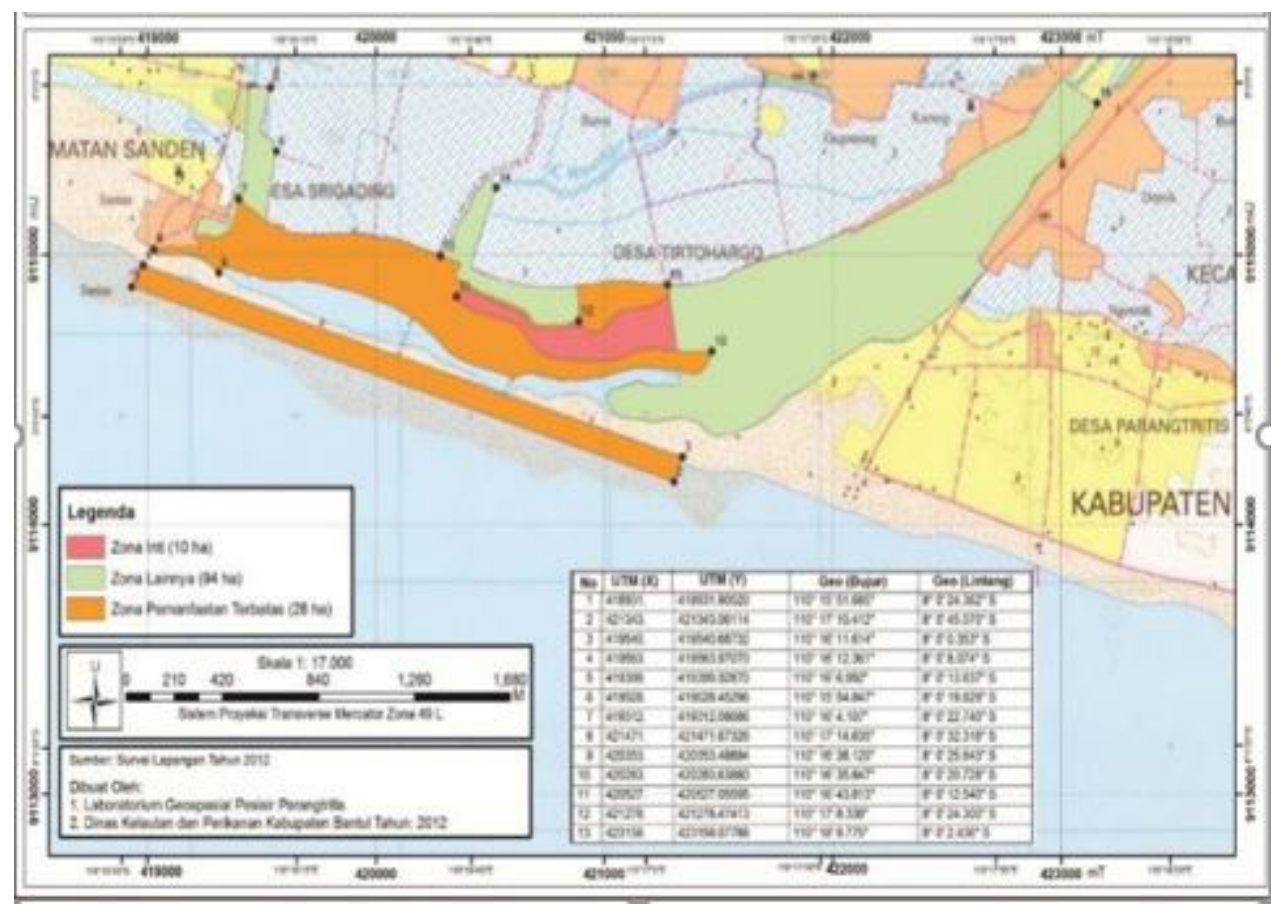

Figure 2. Map of Conservation Areas and Mangrove Coastal Parks

Source: Bantul Regent Decree Number 284 OF 2014

with its management plan, and implementing the management of the Coastal ParkConservation Area in Bantul Regency. Zones are set at several points, strengthened by the issuance of local regulations.

Bantul Regency has taken steps in the form of making policies about biodiversity management and has succeeded in implementing sustainable development in the use and protection of biodiversity for life and future generations. Biodiversity has essential benefits and functions in supporting human life; if it is managed appropriately and adequately, it can be a strategic function for the community, region, and state. Methods or approaches such as conservation, zoning of use, protecting areas by issuing regulations, adding habitat, and empowering the community by providing training, care, and education aim at limiting human/community who utilize the products of biological natural resources for their lives without thinking about how to conserve and protect them. The biological resources are conserved in order to be used and can support the lives of future generations.

\section{Conclusions}

Biodiversity management is a prerequisite to ensure that natural resources are always available in a sustainable manner for the present and the future. Biodiversity is also the basis for the balance of ecosystems. The maintenance of cultural diversity will promote equal treatment for everyone and make people have knowledge about various societies' traditions and understand them better. There is an agreement between countries in the United Nations (UN) to manage biodiversity and ecosystem management as goals that must be achieved in sustainable development. In keeping biodiversity from becoming extinct and overused by other parties, the government's essential role is needed in its management.

Bantul Regency has issued a policy in the form of a Regional Regulation on biodiversity management. The concepts and strategies in sustainable development carried out by the Bantul Regency government are equity, participation, diversity, integration, and a long-term perspective. Efforts to protect and conserve the ecosystem in Bantul district are carried out with various measures, including that all development and activities that impact the environment have to comply with spatial planning.

The management of biodiversity is carried out by the Bantul Regency Government, namely the conservation management approach or methods such as the conservation of In-Situ in the form of Nature Reserve, Ex- 
situ Mangunan fruit orchards, and conservation of bird, fish, and turtle on several beaches. Besides, the management of ecosystem conservation such as mangroves is a policy issued to prevent extinction and can be used economically to support the community's economy and empower the community which can be continued by the next generation. In sustainable development, biodiversity management needs to be managed by considering the importance of resources or biodiversity for human survival.

\section{References}

Ali, M., Kennedy, C. M., Kiesecker, J., \& Geng, Y. (2018). Integrating biodiversity offsets within Circular Economy policy in China. Journal of Cleaner Production, 185, 32-43. https://doi.org/10.1016/j. jclepro.2018.03.027

Ardiyansari, N. S. M. (2019). Peran Organisasi Pemuda Dalam Pengembangan Ekowisata Kawasan Mangrove Guna Mewujudkan Ketahanan Lingkungan (Studi pada Keluarga Pemuda Pemudi Baros (KP2B) Di Dusun Baros, Desa Tirtohargo, Kecamatan Kretek, Kabupaten Bantul, Daerah Istimewa Yogyakarta). Jurnal Ketahanan Nasional, 25(2), 226-252. https://doi. org/10.22146/jkn.46194

Arianti, D., \& Satlita, L. (2018). Collaborative Governance Dalam Pengembangan Konservasi Mangrove Baros di Desa Tirtohargo Kecamatan Kretek Kabupaten Bantul. Jurnal Adinegara, 7(6), 809-827. Retrieved from http://journal.student.uny. ac.id/ojs/index.php/adinegara/article/ download/13177/12729

Arlis, S., Muhammadi, \& Chandra. (2018). Konservasi Hutan Mangrove Dan Pengembangan Ekowisata Kampung Mangrove Di Medan Labuhan Dan Bagan Serdang. 6, 77-81.

Bahagia, B., Wibowo, R., Mangunjaya, F. M., \& Priatna, O. S. (2020). Traditional Knowledge of Urug Community for Climate, Conservation, and Agriculture. MIMBAR : Jurnal Sosial Dan Pembangunan, 36(1), 240-249. https://doi.org/10.29313/ mimbar.v36i1.5824

Darajati, W., Pratiwi, S., Herwinda, E., Radiansyah, A. D., Nalang, V. S., Nooryanto, B., ... Hakim, F. (2016). Indonesia Biodiversity Startegy and Action Plan (IBSAP) 2012-2020.

Drakel, A. (2010). Kebijakan pengelolaan lingkungan hidup berbasis ekonomi sumberdaya di Propinsi Maluku Utara. Agrikan: Jurnal Ilmiah Agribisnis
Dan Perikanan, 3(1), 90. https://doi. org/10.29239/j.agrikan.3.1.90-100

Duane, Harford, Ramasubbu, Stancliffe, Clewer, Lomax, S. (2019). Environmentally sustainable dentistry: a brief introduction to sustainable concepts within the dental practice. British Dental Journal, 226(4), 292-295. https://doi.org/10.1038/ s41415-019-0010-7

Fatimah, S. S. (2018). Peran Pemerintah Mengelola Sumber Daya Hutan Dalam Rangka. (May).

Ferrier, S., Ninan, K. N., Leadley, P., Alkemade, R., Acosta, L. A., Akçakaya, H. R., ... Wintle, B. (eds. . (2019). Summary for policymakers of the methodological assessment of scenarios and models of biodiversity and ecosystem services of the Intergovernmental Science-Policy Platform on Biodiversity and Ecosystem Services. Secretariat of the Intergovernmental Science-Policy Platform on Biodiversity and Ecosystem Services, (May 2019), 39. https://doi.org/10.1590/16760611201600010001

García-Llorente, M., Harrison, P. A., Berry, P., Palomo, I., Gómez-Baggethun, E., IniestaArandia, I., ... Martín-López, B. (2018). What can conservation strategies learn from the ecosystem services approach? Insights from ecosystem assessments in two Spanish protected areas. Biodiversity and Conservation, 27(7), 1575-1597. https://doi.org/10.1007/s10531-016$1152-4$

Gordon, J. E., Crofts, R., \& Díaz-Martínez, E. (2017). Geoheritage conservation and environmental policies: Retrospect and prospect. Geoheritage: Assessment, Protection, and Management, 213-235. https://doi.org/10.1016/B978-0-12809531-7.00012-5

Gull, S., MA, A., Dar, A. M., Kifle, T. B., Stewart, J., Bennett, M., ... Worte, C. (2017). Mountain Watersheds and Ecosystem Services: Balancing multiple demands of forest management in ... Mountain Watersheds and Ecosystem Services: Balancing. International Journal of Water Resources Development, 33(3), 1-9. https://doi. org/10.1016/j.agwat.2009.09.009

Hardiyanti, M., \& Aminah, A. (2019). Tinjauan Yuridis Terhadap Prinsip Pemberdayaan Masyarakat Dan Pembangunan Berkelanjutan Dalam Pengelolaan Sumber Daya Hutan Di Pulau Jawa. Bina Hukum Lingkungan, 4(1), 135. https://doi. org/10.24970/bhl.v4i1.92

Hermita, N. (2015). agritourism potential 
as conservational effort to realize sustainability development (Case Study in Cinyurup Kampung, Juhut Karangtanjung District, Pandeglang Regency Banten Province). Agrologia, 4(2), 96-104.

Isbell, F., Gonzalez, A., Loreau, M., Cowles, J., Díaz, S., Hector, A., ... Larigauderie, A. (2017). Linking the influence and dependence of people on biodiversity across scales. Nature, 546(7656), 65-72. https://doi.org/10.1038/nature22899

Khairina, E., Purnomo, E. P., \& Malawnai, A. D. (2020). Sustainable Development Goals: Kebijakan Berwawasan Lingkungan Guna Menjaga Ketahanan Lingkungan Di Kabupaten Bantul Daerah Istimewa Yogyakarta. Jurnal Ketahanan Nasional, 26(2), 155. https://doi.org/10.22146/ jkn.52969

Kopnina, H. (2017). Commodification of natural resources and forest ecosystem services: Examining implications for forest protection. Environmental Conservation, 44(1), 24-33. https://doi.org/10.1017/ S0376892916000436

Kuspriyanto. (2015). Dikawasan Lindung Di Indonesia. Https://Journal.Unesa.Ac.Id/, 1(4).

Lepczyk, C. A., Aronson, M. F. J., Evans, K. L., Goddard, M. A., Lerman, S. B., \& Macivor, J. S. (2017). Biodiversity in the City: Fundamental Questions for Understanding the Ecology of Urban Green Spaces for Biodiversity Conservation. BioScience, 67(9), 799-807. https://doi.org/10.1093/ biosci/bix079

Lin, Y. P., Lin, W. C., Wang, Y. C., Lien, W. Y., Huang, T., Hsu, C. C., ... Crossman, N. D. (2017). Systematically designating conservation areas for protecting habitat quality and multiple ecosystem services. Environmental Modelling and Software, 90, 126-146. https://doi.org/10.1016/j. envsoft.2017.01.003

Liu, C., \& Côté, R. (2017). A framework for integrating ecosystem services into China's circular economy: The case of eco-industrial parks. Sustainability (Switzerland), 9(9). https://doi. org/10.3390/su9091510

Moore, A., Ndobe, S., Ismi, A., Salanggon, M., \& Wahyudi, D. (2015). Biodiversitas dan Isu-Isu Pengelolaan Coral Reefs of Sonit Island, Banggai Archipelago: Biodiversity and Management Issues. Simposium Nasional Kelautan Dan Perikanan, Makassar II, 9 Mei 2015, 1-8.

Mudjia, R. (2017). STUDI KASUS DALAM PENELITIAN KUALITATIF: KONSEP DAN
PROSEDURNYA. (April), 15-16.

Opoku, A. (2019). Biodiversity and the built environment: Implications for the Sustainable Development Goals (SDGs). Resources, Conservation and Recycling, 141(October 2018), 1-7. https://doi. org/10.1016/j.resconrec.2018.10.011

Pramono, M. F., Lahuri, S., \& Ghozali, M. (2020). Disaster Resilient Village Based On Sociocultural Aspect in Ponorogo. MIMBAR : Jurnal Sosial Dan Pembangunan, 36(1), 63-73. https://doi.org/10.29313/ mimbar.v36i1.5194

Prip, C. (2018). The Convention on Biological Diversity as a legal framework for safeguarding ecosystem services. Ecosystem Services, 29(August 2016), 199-204. https://doi.org/10.1016/j. ecoser.2017.02.015

Purnomo, E. P., Nurmandi, D. (2016). Ekologi Pemerintahan: Tata Kelola Dan Kelembaman Birokrasi Dalam Menangani Kebakaran Hutan, Pengelolaan Sawit, Serta Peranan Elit Lokal. i-234.

Purnomo, E. P., Ramdani, R., Agustiyara, Tomaro, Q. P. V., \& Samidjo, G. S. (2019). Land ownership transformation before and after forest fires in Indonesian palm oil plantation areas. Journal of Land Use Science, 14(1), 37-51. https://doi.org/1 $0.1080 / 1747423 X .2019 .1614686$

Rahadian, A. H. (2016). Strategi Pembangunan Berkelanjutan. Prosiding Seminar STIAMI, III(01), 46-56. https://doi.org/23552883

Rahardjo, M. (2018). Studi Fenomenologi itu Apa? 4.

Rees, S. E., Foster, N. L., Langmead, O., Pittman, S., \& Johnson, D. E. (2018). Defining the qualitative elements of Aichi Biodiversity Target 11 with regard to the marine and coastal environment in order to strengthen global efforts for marine biodiversity conservation outlined in the United Nations Sustainable Development Goal 14. Marine Policy, 93(October 2016), 241-250. https://doi.org/10.1016/j. marpol.2017.05.016

Rosana, M. (2018). Kebijakan Pembangunan Berkelanjutan Yang Berwawasan Lingkungan di Indonesia. KELOLA Jurnal Ilmu Sosial, 1(1), 148-163.

Setyaningrum, E. W. (2017). Pelestarian Mangrove Berbasis Masyarakat Sebagai. Seminar Nasional Pengabdian Kepada Masyarakat, 313-321.

Temel, J., Jones, A., Jones, N., \& Balint, L. (2018). Limits of monetization in protecting ecosystem services. Conservation 
Biology, 32(5), 1048-1062. https://doi. org/10.1111/cobi.13153

Tristyana, E. N. (2018). Pengelolaan sungai code sebagai ekowisata di yogyakarta. (May).

UNDP. (2016). Biodiversity and the 2030 Agenda for Sustainable Development Biodiversity Is Essential for Sustainable Development. Retrieved from https://www. cbd.int/development/doc/biodiversity2030-agenda-technical-note-en.pdf

United Nations. (2015). Financing the 2030 agenda for sustainable development. Governing Through Goals: Sustainable Development Goals as Governance Innovation, 16301(October), 259273. https://doi.org/10.7551/ mitpress/9780262035620.003.0011

Widyanto, A., Mulatsih, S., \& Karlinasari, L. (2019). Pemberdayaan Masyarakat dalam Pelestraian Hutan dan Pertanian Berkelanjutan di Sekitar Suaka Margasatwa Karakelang, Sulawesi Utara. Jurnal Pengelolaan Sumberdaya Alam Dan
Lingkungan (Journal of Natural Resources and Environmental Management), 9(4), 1019-1031. https://doi.org/10.29244/ jpsl.9.4.1019-1031

Yahya, H. (2016). Pendekatan Ekosistem Sebagai Upaya Pengelolaan Kawasan Gumuk Pasir Di Parangtritis Bantul D.I. Yogyakarta. KEANEKARAGAMAN HAYATI PENYAKIT BUSUK BATANG JERUK (Botryodiplodia Theobromae Pat.) DI JAWA TIMUR Biodiversity Of Citrus Stem Rot Disease (Botryodiplodia Theobromae Pat.) In East Java, 2(1), 1019-1028.

Zhang, L., Luo, Z., Mallon, D., Li, C., \& Jiang, Z. (2017). Biodiversity conservation status in China's growing protected areas. Biological Conservation, 210, 89-100. https://doi. org/10.1016/j.biocon.2016.05.005 